\title{
Africa's Economic Development In The Global Context: The Influence Of External Economic Factors On Policy-Making And Management In The Continent
}

\author{
Prof. Wilfred A. Ndongko ${ }^{1} \&$ Dr. Uwem Essia ${ }^{2}$ \\ Department of Economics University of Calabar Calabar, Nigeria
}

\begin{abstract}
International linkages, capital movements, and trade relations unleash enormous growth opportunities for poor countries: such opportunities include larger and deepened trade openings, managerial and production innovations, tourism, carbon credits, improved access to information and communication technology, amongst others. But Sub Saharan African (SSA) countries generally face unfavourable initial conditions: inequitable trade relations, price volatility, heavy external indebtedness, oil market shocks, and capital flight; and their capacity to deal with these challenges is hampered by weak competitive competence, low absorptive capacity, poor planning and policy implementation, and non-compatibility with changing global realities. This paper examines how challenges posed by the aforementioned external factors, and the internal incapacities, affect growth and development in the SSA region. The paper concludes that African countries should look inwards, by individually and collectively addressing the internal incapacities to enhance the capacity to deal with the external factors.
\end{abstract}

Key Words: External Factors, competitive competence, external shocks, policy failures, capital flows, debt burden.

\section{Background}

International linkages, through trade and migration, ICT, sports and games, tourism and cultural exchange among others have made development in one country to be patently linked to what happens elsewhere. The Economic Report on Africa by the United Nations Economic Commission for Africa (ECA, 2007) identifies demand for exports, balance of payments, remittances, and external borrowing as key channels through which the external sector impacts on the local economy. The external environment unleashes enormous opportunities for growth and development. Such opportunities include larger and deepened trade openings, managerial and production innovations, tourism, carbon credits, improved access to information and communication technology, amongst others . But these opportunities are associated with challenges imposed by competitive competence, capital absorption, policymaking, and compatibility with changing global realities (Ndongko, 1995; Mahmond, 1994; ECA, 2007). This paper examines how these and other related challenges have impacted on the ability of countries in the Sub Saharan African region in recent times. The key issues addressed are: the weak competitive capacity of Africa in global trade; fluctuations in produce prices as a major cause of policy failures in African countries; decreasing external capital inflow to African economies, huge external debt burden; oil prices shocks; and the impact of economic recessions in the industrialized countries on economic management in Africa.

\section{Competitive competence in external trade}

There is broad acceptance that poor countries of Asia, Latin America, and Africa have generally faced unfair conditions in global trade. The General Agreement on Tariffs and Trade (GATT) was created in 1947 to promote mutually beneficial international trade. In 1970, developing countries proposed the New International Economic Order (NIEO) to the United Nations Conference on Trade and Development (UNCTAD), to promote and enhance the economic interests of less developing countries by improving their terms of trade, ensuring increasing development assistance, and tariff reductions by the industrialized nations. The NIEO sought to revise the Bretton Woods system that was seemingly more beneficial to the developed nations that created it (notably the United States of America). The U.N. General Assembly adopted the proposals and the protocols of the NIEO but no actions were taken to implement them (Makler et. al., 1982)

The birth of the World Trade Organisation (WTO) in 1994, as an outcome of the Uruguay Round of Trade Negotiations, totally changed the face of world trade. The fundamental principles of the WTO included: non-discrimination, prohibition of quantitative restrictions, and consolidation of previously imposed customs duties. The subsequent expansion of world trade following the creation of the WTO is undeniable: total world exports increased from US\$ 6,451 billion in 2000 to US\$ 10,393 billion in 2005, representing a $61 \%$ increase; 
Africa's economic development in the global context: the influence of external economic factors on and African exports grew at an average rate of $16 \%$ per annum over the same period (5.6\% above the world average of about $10.4 \%$ per annum).

The impressive performance notwithstanding, African countries still face major challenges in defining and defending their positions in technical negotiations even on issues that are of key strategic interest to them. Such incapacities are major setback in economic policy-making and effective management. In addition, the cheapening effects of products from the emerging economies of Asia such as China, Korea and India have made basic manufactures from Africa largely non-competitive (Qureshi, 1996; Safadi and Laird, 1996; ECA, 2007, ADB, 2006).

\section{II.1 The New International Monetary System}

The new international monetary system seem not to have given due consideration to the unfavourable initial conditions in the SSA region. It is widely argued that the dehumanizing and destruction effects of trans Atlantic slave trade Western colonialism contributed to the abysmal performance of many SSA countries today. Both experiences denied SSA countries the opportunity to evolve the technostructure that can promote technological progress. In effect therefore, the cultural milieu that eased technological progress in today's developed societies does not seem to exist in SSA countries.

Rather, foreign influence and disruptions built and is sustaining the culture of over-dependence on imported consumables and machineries on the one hand (import addiction), and the indispensability of foreign exchange derived from the export of primary produce (export bias) on the other hand. Put together, import dependence and export bias is at the core of stagnated development and unfavourable terms of trade in the SSA region at present (ECA, 2007).

African leaders have always canvassed for understanding and fair treatment, considering Africa's unfavourable initial conditions. But their expectations and that of others in these regards are scarcely met. Hope of possible improvement in the future is dampened by growing internationalization of finance and decentralization of global trade occasioned by emergence of several newly developed countries and regional economic groupings, and the growing loss of control on global trade and exchange by IMF and World Bank.

\section{II.2. Vulnerability to External Shocks}

Import addiction and export bias render SSA countries increasingly vulnerable to external shocks: beginning with the international financial markets' turbulence since the 1980s (a result of dollarization of the global economy); to the recession in OECD countries in the 1990s and early 2000s; and the recent global economic meltdown that began in 2007. Arising from their generally weak economies, poor countries tend to gain much less from upswings and lose much more to downswings relative to the fast moving economies.

The surge of private commercial banks since the 1980s and revolutions in e-finance have also made money laundering and capital flight from Africa much easier. Furthermore, variability of interest and exchange rates has remained high as capital markets and the foreign exchange markets become digitalized and linked globally. These markets tend to respond more to activities of private commercial banks than operations of the World Bank and the IMF. For this reason, many Western private banks have relocated to emerging countries, thus further reducing financial flows to the African continent (ECA, 2007).

Adoption of the single currency in Europe (EURO) on the $1^{\text {st }}$ January 1999, the collapse of communism and the subsequent financial flows from Western Europe and North America to the defunct Soviet bloc economies, and growing wave of regional economic cooperation among the advanced economies and the newly developed economies have considerably deprived Africa of the much needed foreign finances (BoafoArthur, 1992). Even with the liberalization of world markets, African countries still find it difficult to penetrate the European markets because of so many tariff and non-tariff barriers, despite the Lomé Conventions. At the same time, Africa's export produces have been made comparatively expensive due to the subsidies that advanced countries grant to their local producer, particularly farmers.

African countries also face the negative aspects of the New Economic Partnership for African Development (NEPAD), which many see as an unequal commercial agreement since African countries produce very few manufactures. NEPAD tends to promote heavy importation of manufactures by African countries from the EU at high prices to the detriment of indigenous manufacturers. Sadly enough, regional economic organisations and trading blocs in Africa have not lived up to expectation (ECA, 2007; Lawrence. Sommers and Merhatu, 1992).

Equally, Africa lags behind the rest of the world in the development of Information and Communications Technology (ICT), which has become a key facilitator of modernization. ICT is the main instrument of international banking and finance, trade, education and health; new products are advertised through the numerous satellite, radio and TV networks. These ICT medias are owned and largely controlled by firms and individuals in advanced countries, and quite naturally the interest and concerns of African countries are hardly given fair consideration. 
Africa's economic development in the global context: the influence of external economic factors on

\section{Price fluctuations and policy failures}

Volatility of produce prices and demand quantities make reliable forecasts of foreign exchange earnings more difficult to obtain; rendering budgets and economic plans unrealistic and non-credible in many African countries. Since the 1980s, Africa and particularly Sub-Saharan Africa, has been experiencing the crisis of falling commodity prices and rising import prices (Collier \& Gunning, 1996). This has reduced the continents' share in world merchandise exports from $6.3 \%$ in 1980 to $2.5 \%$ in 2000 , and led to further worsening its terms of trade. For example, the price of cocoa on the world market began to worsen in the 1980s as it fell by $50 \%$, and towards the end of the decade (1990), the terms of trade fell by $31 \%{ }^{1}$. The share of Africa in world exports declined from $3.1 \%$ in 1990 to $2.2 \%$ in 2002 and then rose again to $2.9 \%$ (in 2005) due to increasing commodity prices ${ }^{2}$. These figures reflect great variability in world commodity prices, particularly as primary produce and raw material exports contribute substantially to export earnings of most African countries.

In Cameroon, for example, the contribution of exports to GDP has varied between $30 \%$ and $33 \%$, since the 1980s. As a result of the general deterioration in the terms of trade recorded all over Africa by 1987, Cameroon's growth rate fell from $6.77 \%$ in 1986 to $-2.15 \%$ in 1987 . This negative growth trend persisted until 1995 when positive growth returned to 3.3\% in 1995 and 5.04\% by 1998 (World Bank, 2006).

In some other African countries also, dependence on non-fuel commodity exports has even been greater; with cocoa exports representing about 34\% of total exports between 2000 and 2004 in Côte d'Ivoire and coffee exports representing $43 \%$ of total exports during the same period in Burundi ${ }^{3}$. In the case of Zambia, copper exports represented $57 \%{ }^{4}$ of total exports in 2005, and the increase in copper prices on the world market significantly contributed to the country's growth rate of over 5\% during the period 2002-2005. During periods of price slumps, which often last longer than booms, the meagre income earned by local producers generally discourage further production and leads to a reduction in output. In Cameroon, for example, coffee exports dropped from 124,000 metric tons in 1986 to only 67,000 metric tons in 1993, due to a sharp decrease in coffee prices on the world market. Clearly fluctuations in commodity prices do constrain policy making and economic management in Africa.

Variations in exchange rate equally account for poor planning and policy failures. Fluctuating exchange rates generally tend to increase the cost of imports in the SSA region. In Cameroon, imports were evaluated at US $\$ 2.12$ billion (about $87.24 \%$ of the value of total exports) in 1980 and increased to US $\$ 2.38$ billion (87.5\% of the value of total exports) in 2000. Within the same period, the FCFA/US\$ exchange rate rose from 329 Frs. CFA to 712 Frs. CFA; with imports consuming $80 \%$ to $97 \%$ of their export value, making it difficult for most SSA countries to adopt pro-growth economic policies.

Indeed, African countries could earn more from produce exports if their export produce prices do not fluctuate arbitrarily. For instance the UNCTAD research on African coffee and sugar exporting countries revealed that these countries could have earned US $\$ 1.9$ billion and US $\$ 1.4$ billion, respectively. At the same time, West African cotton producing countries could have also earned US $\$ 1$ billion if the prices for these products had not fallen between 1999 and 2002. In terms of relative price falls in 2001, coffee and cotton lost $35 \%$ and 19\%, respectively, in Benin, Burkina Faso, Mali and Chad; fish 21\% in Senegal and copper 13\% in Zambia (ADB, 2006; World Bank, 2006).

It is noteworthy that export and import prices have also been influenced by Multinational Corporations (MNCs) through transfer pricing. It is now common knowledge that the subsidiaries of MNCs generally carry out intra-firm trade especially in primary commodities and extractive minerals (produces of African countries) with a view to reducing prices. Equally, subsidies and preferential treatment given to local producers in the developed countries (despite the WTO agreements) have cheapened agricultural produce of the advanced economies and make them more competitive than the produce of African countries. For example, the EU agricultural policy led to an increase in its exports by 55\% (about 22 million tons between 1980/1981 and 1991/1992) with an increase in the market share of 6\%. In the same vain, cotton subsidies in the USA led to increased production by $\$ 3-4$ million USD per year and about $40 \%$ increase in exports. These external factors have impacted negatively on the ability of African countries to plan and implement development programmes effectively and efficiently (Herbst, 1996; Ndongko, 1996).

\footnotetext{
${ }^{1}$ Ben Turok (ed), Alternative Strategies for Africa: Debt and Democracy, vol. 3, Institute for African

Alternatives, London, 1991, p.7

${ }^{2}$ Economic Commission for Africa, Economic Report on Africa 2007: Accelerating Africa's Development through Diversification, Addis Ababa, February 2007, p.24

${ }^{3}$ World Bank, World Development Indicators, Washington D.C., 2006

${ }^{4}$ Economic Commission for Africa, op cit, p.22
} 
Africa's economic development in the global context: the influence of external economic factors on

\section{Decreasing external capital flows}

The received neoclassical economic theory predicts that capital should flow from rich countries (where it is plenty and relatively cheap) to poor countries (where it is scarce and more expensive). However, since 1914, the flow of capital to Africa has been quite minimal. This is attributable to low absorptive capacity arising from the weak legal framework, inadequate institutional guarantees and incentives, and poor infrastructures and social amenities. Since the 1990s capital inflow to Africa has been declining. Out of the US\$ 1.2 trillion global capital flows in 2006, only US\$ 38.8 billion went to Africa, and about $50 \%$ of this found its way into the oil industry in Nigeria and Angola (World Bank, 2006).

Inadequate inflow of private capital has substantially dampened growth in the private sectors of African countries. This could be measured by the very weak private sector contribution to the GDP of African countries. For example from $14.1 \%$ in 1980 and $13.5 \%$ in 1993, it marked an insignificant rise up to $15.3 \%$ in 2002. The minimal increase is attributable to the oil industries of Nigeria, Gabon, and Angola and to the manufacturing industries of Morocco and Tunisia (World Bank, 2006).

A number of reasons have been adduced to explain why the traditional pattern of capital flows from the developed countries to the less developed countries in conventional trade theories has seemingly been replaced by the increasing flow of capital among the developed economies:-

- Firstly, the 1980's saw industrialized countries with budget deficits and high interest rates attracting funds that were used to finance consumption and transfers rather than productive investment.

- Secondly, the emergence of former Soviet bloc economies in the global economic scene shortchanged Africa's chances, as investment conditions in those economies were relatively more attractive.

- Thirdly, capital flows are increasingly dampened by responses of investors to exchange rate and interest rate risks, resulting from floating exchange rates in many African countries.

- Fourthly, the extension of financial markets, to include the intermediation of financial risks, contributed to the increase in short-term capital transactions in the 1980's, and has made the control of capital flows extremely difficult for many African countries since then.

- Fifthly, repayment difficulties have increased the associated risks involved in lending to heavily indebted less developed countries, particularly African countries.

Generally, the decrease in gross public capital flows has had negative impact on Africa's economic growth and development, and its contribution to GDP in percentage terms has steadily decreased across Africa. In North Africa for instance, from 9.4\% in 1993, it dropped to $7.5 \%$ in 1995 and 6.8\% in 1996; and the trend has been the same in SSA, where it decreased from $5.9 \%$ in 1993 to $5.4 \%$ in 2000 (ECA, 2007).

\section{IV.1. Donor Support and Development Partnership Programmes}

Shifts in the priorities of donor countries and international financial institutions are increasing determined by the following factors:-

$\rightarrow \quad$ Political and democratic pluralism

$\rightarrow \quad$ Good governance, transparency and accountability

$\rightarrow \quad$ Market-based economic policy reforms and adjustment programmes

$\rightarrow \quad$ Environmental and sustainable development considerations

$\rightarrow \quad$ Poverty alleviation and employment creation

$\rightarrow \quad$ Public Health Concerns (HIV/AIDS, tuberculosis, malaria, etc)

$\rightarrow \quad$ Emergency Assistance

These enablers of donor funding are generally linked to attainment of the Millennium Development Goals (MDGs) set for 2015. African countries have generally instituted reforms to meet the time line for the MDGs, but many are still far behind, making Africa a less preferred destination for donor funds.

In the light of the foregoing analysis, it is obvious that decreasing external private capital flows and public financial resources have seriously influenced economic policymaking and rendered its management more complex. Consequently, achieving positive results from the implementation of economic policies has depended largely on the ability of policy-makers and planners to predict and efficiently integrate these external factors into the formulation and implementation of national development policies in Africa.

\section{External debt crisis}

Development theory maintains that external borrowing is likely to enhance economic growth in developing countries, as they need to undertake heavy investments, which cannot be financed solely by their unpredictable earnings. However, Agho (2002) rightly argues that external borrowing is beneficial when the growth rate of income is greater than, or at least equal to the growth rate of the external debt servicing. But the global economic crisis of the early 1980s promoted the mismatch between growth rates of income and cost of debt servicing in many African countries; leading to frequent debt default that rendered the external debt burden unsustainable (Degefe, 1992). 
Africa's economic development in the global context: the influence of external economic factors on

Equally worrisome is the fact that many African countries borrowed from commercial banks with little or no interest payment concessions. African governments certainly preferred concessional loans from both multilateral and bilateral lenders, but their inability to meet up with debt service obligations led to reticence amongst its traditional lenders, leaving them with commercial banks as avenues for sourcing finances to fill funding gaps. In the case of Cameroon, debt servicing on bilateral unconcessional loans grew from US\$ 36.2 million in 1982 to US\$ 111 million in 2000 (representing a 206.6\% increase), whereas GDP rose only from US\$ 7.32 billion to US $\$ 8.88$ billion ( $21.3 \%$ increase) within the same period.

Following the oil boom of 1973/1974 and 1970/1981, many African countries obtained cheap bilateral and private loans. In fact, the commodity booms of this period encouraged large-scale borrowing to sustain high levels of spending which were difficult to reduce after the boom collapsed. Unfortunately, the commodity booms were short-lived, and thus plunging the African countries into cumulative debt crisis. The long-term accumulation of external debt has led to a loss of international credit worthiness. As a result, in the 1980s some of these countries have been classified as heavily indebtedness poor countries.

By 2000 some fourteen countries in Africa were placed under the HIPC initiative, with the objective of reducing their debt servicing obligations to sustainable levels. Some of these countries include Cameroon, Senegal, Uganda, Rwanda and Benin. It is hard to determine how well cancellation of debts for some African countries has improved the socio-economic situation of those countries considering the stringent conditions of the IMF and World Bank, relating to the utilisation of the debt relief funds (African Development Bank, 1993; Aliber, 1980; Cline, 1985; Greene, 1989; Krumm, 1985; Minstry, 1988; Greene, et. al. 1990)

The implication of the external debt crisis on policy-making and economic management in Africa is best illustrated by the impact of large external debt service obligations on the level of domestic investments. Again in Cameroon, since the 1986 world economic crisis and until 2000, the level of budgetary investment barely doubled (from FCFA 56.4 billion in 1982 to FCFA 2170 billion in 1982 to FCFA 5830 billion in 2000). Without being exclusive to Cameroon alone, the external debt of other sub-Saharan African countries has had a negative impact on budgetary investment and hence, on economic growth. For example, countries like Ethiopia have seen their external debt grow tremendously over the past quarter of the century, from US\$ 343.7 million (about 14\% of its GDP) to US\$10.2 billion (above 214\% of GDP) in 1999.

Nigeria's external debt history began in the 1970s, but its negative manifestations showed-up in the 1980s and 1990s (Ajaji, 1991). Ojo (1994) recounts trends in external debt stock and structure of LDCs as maintaining a strong upward trend between 1980 and 1987, at an average of 12.7 percent per year. Nigeria's external debt grew from US\$ 9 billion in 1980 to US\$ 19 billion in 1985. By December $31^{\text {st }} 2002$, the country's external debt stock amounted to $\$ 28.273$ billion, which was about 74 percent of GDP and 178.5 percent of export earnings (Nwankwo, 2002). However, a debt relief deal in 2006 reduced Nigeria's external debt stock significantly to less than $\$ 3$ billion by 2007 . That deal signalled Nigeria's temporary exit from the list of highly indebted underdeveloped countries. But high import dependence and export bias still make Nigeria highly vulnerable to heavy external indebtedness, if policy makers ignore past experiences.

For sub-Saharan Africa, as a whole, the ratio of external debt to export of goods and services grew from $119.7 \%$ (in 1980) to $269.8 \%$ (in 1995) while the ratio of debt service to exports grew from $7.8 \%$ to $14.7 \%$, during the same period. The magnitude of external debt and debt service ratios of the developing countries, including Sub-Sahara are presented in Table 1. These figures reveal how external debt impacts adversely on policy-making and budget performance in SSA countries; by consuming substantial proportions of export earnings, servicing of external debt leaves very limited resources for investments and other growth projects.

\begin{tabular}{|c|c|c|c|c|c|c|c|}
\hline & \multirow{2}{*}{\begin{tabular}{|c|}
$\begin{array}{c}\text { Extemal Debt } \\
\text { (Sbililions) }\end{array}$ \\
1999 \\
\end{tabular}} & \multicolumn{3}{|c|}{ Debt as percentage of Gross Domestic Product } & \multicolumn{3}{|c|}{$\begin{array}{l}\text { Debt as percentage of Expots of } \\
\text { Goods and Services }\end{array}$} \\
\hline & & 1999 & 2000 & 2001 & 1999 & 2000 & 2001 \\
\hline \begin{tabular}{|l|} 
All Developing \\
Countries
\end{tabular} & $\$ 2,038.2$ & $38.3 \%$ & $35.5 \%$ & $34.4 \%$ & $163.2 \%$ & $145.6 \%$ & $141.6 \%$ \\
\hline Africa & 311.5 & 73.2 & 68.9 & 67.7 & 244.4 & 205.4 & 208.4 \\
\hline Asia & 671.0 & 29.4 & 26.6 & 25.1 & 115.1 & 103.5 & 97.0 \\
\hline \begin{tabular}{|l|} 
Middle East and \\
Europe
\end{tabular} & 295.7 & 38.0 & 35.0 & 35.8 & 123.1 & 104.7 & 111.3 \\
\hline $\begin{array}{l}\text { Westem } \\
\text { Hemisphere } \\
\text { (Latin America) }\end{array}$ & 759.9 & 41.3 & 39.3 & 38.3 & 254.9 & 232.9 & 221.6 \\
\hline
\end{tabular}

Table 1. External debt and debt ratios of the developing countries 


\begin{tabular}{|l|c|c|c|c|}
\hline & $\begin{array}{c}\text { Extemal Debt } \\
\text { (\$ billions) }\end{array}$ & \multicolumn{3}{|c|}{ Debt Service Ratio } \\
\cline { 2 - 5 } & 1999 & 1999 & 2000 & 2001 \\
\hline All Developing Countries & $\$ 2,038.2$ & $27.8 \%$ & $23.3 \%$ & $21.7 \%$ \\
\hline Africa & $\mathbf{3 1 1 . 5}$ & $\mathbf{2 2 . 9}$ & $\mathbf{2 2 . 3}$ & $\mathbf{2 1 . 9}$ \\
\hline Asia & 671.0 & 18.7 & 13.5 & 13.3 \\
\hline Middle East and Europe & 295.7 & 16.6 & 18.8 & 17.1 \\
\hline $\begin{array}{l}\text { Westem Hemisphere } \\
\text { (Latin America) }\end{array}$ & 759.9 & 56.7 & 46.0 & 41.1 \\
\hline
\end{tabular}

Source: World Bank Debt Tables, 2003

\section{Oil price shocks}

There have been three key actors in the determination of crude oil prices, namely; multinational oil companies, the Organisation of Petroleum Exporting Countries (OPEC), and more recently market-related pricing system, which links oil prices to the market price of particular reference crude oils (Farrell, Kahn, \& Visser; 2001). The major oil price shocks include; the first oil shock (1973/1974), the second oil shock (1979/1980), the third oil shock (1990), the fourth oil shock (2003/2004), and the oil shock of 2007. The 1973 oil shock was a sharp increase in oil prices following the Arab oil embargo. The 1979/1980 oil shock was a sharp fall in oil prices following monetary tightening measures by the US. The 2007 shock was an initial sharp increase in oil prices following a boom in the advanced economies and other fast growing economies, particularly China, which was followed by a sharp decline 2009 as the global economic meltdown deepened.

Unlike Europe and America that have increasingly been investing in research on alternative sources of energy (notably bio-fuels), Africa depends largely on petroleum oil and gas as its main energy sources. This has made the demand for oil and gas in Africa to be price inelastic, and the continent to be most vulnerable to sudden oil price variations. As a result, the non-oil exporting African countries have had to draw on their foreign reserves in order to fill the energy cost-gap, and doing so constitute enormous costs to African countries. To this extent, therefore, it is clear that oil prices represent an important external factor in economic policy-making and management in Africa, for both oil-importing and exporting nations.

Yet, African countries lack any form of control over oil prices and therefore succumb to the dictates of the major players in the international oil market (Farrell, Kahn, \& Visser, 2001). The doubling and eventual quadrupling of world prices of oil has impacted negatively on macroeconomic variables in net oil-importing countries of Africa.

Beyond the fact that some countries like Nigeria, Angola, Algeria, Equatorial Guinea, Chad, Gabon and Cameroon are net exporters of oil, the majority of African economies are net importers of oil. In Nigeria, these price hikes led to increased social tension and labour unrest in 1978, and while prices increased by $15 \%$, GDP decreased by 5.8\% due to the low level of production caused by labour unrest. There is no doubt that oil price shocks have influenced the outcome of economic policies negatively in SSA countries (Morton, 2007; Nkomo, 2006; Wakeford, 2006).

\section{Recessions in industrialised countries}

During the 1960s, economic growth and improvements in the standards of living were already visible in many industrialised countries and in developing nations. The prices of primary products were relatively stable, and external public assistance to development to African countries was on a regular increase. However, by the end of the $20^{\text {th }}$ century the economies of the OECD countries were, for the first time in decades, experiencing low growth rates (1.7\% on average). The real GDP growth in OECD countries stood at $2.8 \%$ between 1983 and 1993, 2.0\% in 1998 and projections for $1997-2000$ were 2.4\%. The stagnation of markets of industrialised countries, depressed prices for non-oil commodities and the unsustainable debt burden of poor countries began to characterise the global economy, especially economies of developed countries, which are the major sources of loans and grants for developing countries (Essa, 1995).

It should be noted that African economies grew reasonably fast up to 1973, when their growth was challenged by the recession in industrialised countries, especially in the OECD and EU. Between 1965 and 1980, the GDP of Sub-Saharan Africa grew annually by 4.2\% but dropped to 2.1\% between 1980 and 1990 . Sectoral data reveals that policy making in agriculture has been poor and performance has varied considerably between and within countries. Of the 25 countries for which World Bank data was available by 1980, the fastest growth rate of $(10.7 \%)$ was recorded in Libya, Botswana $(9.7 \%)$ and Tunisia $(5.5 \%)$.

Industry faces the same challenges. For example, this has been reflected by the decrease in industrial annual growth rates from 24\% to $-4.3 \%$ in Botswana between 1965 and 1980. Between 1980 and 1990 manufacturing accounted for about 16\% of GDP in 21 of African countries (World Bank; 1994). The temporal and structural links between Africa and Western Europe clearly demonstrate that the recession in the 
Africa's economic development in the global context: the influence of external economic factors on industrialized countries have for a very long time played a preponderant role in dampening economic performance in Africa.

\section{VII.1. Global Economic and Financial Crisis (Since 2007)}

The global economic crisis of 2007 was unprecedented in severity of credit contraction (credit crunch \& capital crunch), and likened to the Great Depression (1928-1939). The financial crisis started in the United States of America (USA) with sub-prime mortgage crisis, but by the fourth quarter of 2008, increased delinquency rates spilled over into consumer and other credits. Immediate outcomes of the financial crisis were: rising liquidity crunch - banks stopped lending and recalled some of their loans, leading to potential financial instability; stock markets burst, which put pressure on banks to raise capital; huge write-downs and downgrading of ratings; and expectations of global recession. All these led to takeovers and bankruptcy; loss of jobs; loss of confidence in financial markets, which made it difficult for banks to carry out their intermediation role in the economy; and stock markets crashes globally, leading to confidence crisis and weak consumer demand.

Table II shows how selected world stock market indices depreciated during the period December 2007 to November 2008 due to the global economic crisis. Stock prices in Russia were worse hit (RTS fell by $72.9 \%$ ); followed by China (63.3\%), and Ghana (60.7\%). In Nigeria stock market indices fell by $35.6 \%$.

Table II. Selected World Stock Market Indices, \% Change (December 2007-November 14, 2008)

\begin{tabular}{|l|l|l|l|}
\hline Stock Market Index & $\%$ Change & Stock Market Index & Change \% \\
\hline Argentina (MERV) & $(52.8)$ & Japan (Nikkei) & $(44.7)$ \\
\hline Australia (ALL Ord) & $(42.0)$ & Malaysia & $(40.8)$ \\
\hline Belgium (Bel 20) & $(50.1)$ & Mexico (BOLSA) Index & $(33.3)$ \\
\hline Brazil (BVSP) & $(44.0)$ & Nigeria (NSE) & $(35.6)$ \\
\hline Britain (FTSE 100) & $(34.6)$ & Poland (WIG) & $(52.0)$ \\
\hline Canada (S \& P TSX) & $(33.3)$ & Russia (RTS) & $(72.9)$ \\
\hline Chile (IGPA) & $(14.4)$ & Saudi Arabia (Tadawul) & $(50.3)$ \\
\hline China (SSEA) & $(63.3)$ & Singapore & $(49.2)$ \\
\hline Egypt (Case 30) & $(54.3)$ & South Africa (JSE AS) & $(34.1)$ \\
\hline Emerging Market (MSCI) & $(57.4)$ & South Korea (KOSPI) & $(42.6)$ \\
\hline France (CAC40) & $(41.8)$ & Spain (Madrid SE) & $(43.1)$ \\
\hline Germany (DAX) & $(42.2)$ & Switzerland (SMI) & $(31.5)$ \\
\hline Ghana (GSE-All Share) & $(60.7)$ & Turkey (ISE) & $(54.7)$ \\
\hline Hong Kong (Hang Seng) & $(51.3)$ & USA (DIJA) & $(33.9)$ \\
\hline India (BSE) & $(53.7)$ & USA (S\&P 500) & $(40.5)$ \\
\hline Isreal (TA-100) & $(48.5)$ & $\begin{array}{l}\text { World Developed Market } \\
\text { (MSCI) }\end{array}$ & $(44.6)$ \\
\hline & & World, all (MSCI) & $(46.2)$ \\
\hline
\end{tabular}

\section{Source: Professor Charles Soludo http://www.cenbank.org/OUT/SPEECHES/2009}

The credit squeeze associated with the financial crisis led to reduced lending to the real sector (on the supply side) and reduced household demand (on the demand side). There were as well adverse wealth effects occasioned by decreasing asset values, which led to loss in consumption, and sharp decline in economic activities. Decreased economic activity resulted in massive job losses in most sectors of the economy. Petroleum prices collapsed by 2009, leading to substantial losses in export revenue, and capital inflows to oil dependent countries like Nigeria. Attempting to meet up the financial commitments of Government also led to deaccumulation of foreign reserves and pressure on exchange rate.

The recent global economic crisis started as a 'financial crisis', and eventually deteriorated to a global economic crisis. The roots are in banking rather than in securities market or foreign exchange. The crisis started in the U.S (due to certain laxities in the US financial system), spread to Europe, and by 2009 became a global crisis, as many countries and markets that were not hit by the first round financial crisis were affected by 'second-round effects' as the crisis now becomes 'economic'.

A number of developments made SSA countries quite vulnerable to the global economic meltdown. In Nigeria for instance, commercial banks went through a number of poorly planned financial innovations; leveraging, swaps, sub-prime lending, etc. Equally, uncoordinated and late interventions by Governments and Central Banks led to loose regulatory regimes, several unregulated financial markets and products, and easy monetary policy; with high liquidity, investor/lenders seek higher returns through riskier investments

Measures taken by countries have been varied, but the actions can be summarized under several categories as follows: interest rate cuts and liquidity injections by Central Banks; capital injections into banks/companies by Governments (e.g. UK \& USA); lending guarantees by Governments to restore liquidity, and reviving the ailing banking system through recapitalization and strengthening of supervision bank deposit guarantees. Other measures include minimizing market disruptions (crackdown on short selling), fiscal Stimulus packages to shore the economy out of recession (e.g. stimulating aggregate demand through subsidies to ailing sectors).

The Central Bank of Nigeria reacted by introducing the following measures: reduction of the MPR from 10.25 per cent to 9.75 per cent; reduction in cash reserve requirement (CRR) from 4.0 per cent to 2.0 per cent; reduction of liquidity ratio from 40.0 per cent to 30.0 percent; directive to banks that they have the option 
Africa's economic development in the global context: the influence of external economic factors on

to restructure margin loans up to 2009; expanded lending facilities to banks up to 360 days; introduced expanded discount window facility; stopped liquidity, and mopping-up since September 2008 (Soludo, 2009).

\section{The implications of external factors for policy making and management in the ssa region.}

(i) Reduced capacity to import essential machinery and intermediate products for industrial development; due to changes in the volume of trade and prices of primary commodities.

(ii) Reduced availability of credit has made it necessary for African countries to cover the current deficits through debt accumulation.

(iii) Loss of international credit worthiness due to inability to meet debt repayment and debt servicing obligations. Deterioration of terms of trade, which has negatively affected current account balances.

(iv) Growing poverty, loss in aggregate demand, and loss of jobs have negatively affected socio-economic development.

\section{THE WAY FORWARD}

Addressing the challenges and problems created by the external economic factors calls for the following measures, among others:-

- Getting the policy instruments and policy mix right. This requires the application of multiple exchange rates systems, differential interest rates policies, selected credit control and price support policies for food production. This calls for research based policies and flexibility in policy implementation.

- Strengthening the capacity to respond to external shocks. Since external shocks often arise from collapse of the international commodity prices, declining export earnings, and reduced external capital flows and heavy debt service obligations, there is need for substantial reduction in import dependence and export bias. Only necessary imports should be allowed, and export of primary produce without value-added should be discouraged. Equally, effort at strengthening regional economic groupings in the continent should be encouraged.

- Achieving congruence between priorities and resource allocation. In order to ensure the most efficient utilization of available scarce resources, commitment to sound planning, budget transparency and accountability, and efficient service delivery. Every form of waste should be avoided.

- Effective human resources development policy and strategy. Since inadequate skills and poor technological knowledge lie at the root of Africa's socio-economic backwardness, commitment to balanced education and other form of human capacity building must be total.

- Commitment to regional and sub-regional economic cooperation and integration. This calls for a demonstration of political will and commitment, and suppression of unnecessary sentiments of the Anglophone and Francophone colonial mix. Africa needs regional economic cooperation to strengthen the collective bargaining power of the continent in the global scene.

- Strengthening the absorptive capacities of African economies - poor infrastructures (for electricity supply, communication, transportation), weak institutional and legal framework, unease of doing business, and weak financial markets account for low absorptive capacity in SSA countries; making the attraction and absorption of foreign capital difficult. Addressing these inadequacies collectively and independently is necessary for gaining more from the global economy.

\section{CONCLUSION}

The objective of this paper was to analyze the impact of external economic factors on policy making and management in Africa. The exercise revealed generally that the factors identified have imparted negatively on the ability and capacity of sub-Saharan African countries in particular, and the entire continent in general, to effectively put in place and implement viable economic policies and prgrammes that could have a long lasting, positive, and visible impact on the population at large.

In view of the foregoing findings, it is imperative that the successful and effective implementation of the recommendations that have been made to address this sad situation require that African countries must be able to develop the internal capacity to enable them counter the negative impact of external economic factors on their national economies. this will call for firm political commitment on the part of African leaders and decision makersas well as the determination of our external development partners to support the objective of making sustainable growth and development of the continent a priority. 


\section{References}

[1] African Development Bank (1994). African Development Report. Abidjan, 1991 - 1993.

[2] Agho, O.O. (2002) “The Origin and Structure of Nigeria's External Debt”. Debt Management Office. Monthly Seminar Series 1, Abuja.

[3] Ajaji. S. I. (1991) Macro-economic Approach to External Debt: The Case of Nigeria. AERC, December.

[4] Aliber, R. Z. (1980) "A Conceptual Approach to the Analysis of External Debt of the Developing Countries." World Bank Papers. No. 421, 1980.

[5] Boafo-Arthur. K (1992) "Europe 1992: A Challenge to Sub-Saharan African Development. Africa Development Vol.XVII, No. 2 .

[6] Cline, W.R. (1985) "International Debt: Analysis, Experience and Prospects.” Journal of Development Planning. No. 16.

[7] Collier P. \& Gunning, J. W. (1996). "Policy Towards Commodity Shocks in Developing Countries" in IMF Working Paper, No. 96/84, Washington D.C.

[8] Dgefe. B (1992) Growth and Foreign Debt: The Ethiopian Experience 1964 - 1986. AERC, November

[9] Economic Commission for Africa (ECA), (2007). Economic Report on Africa 2007: Accelerating Africa's Development through Diversification. Addis Ababa, February.

[10] Essa. B. (1995) "Africa and the International Economic Order." Africa World Review. May/October.

[11] Farrell G.N. Kahn B. \& Visser F.J. (2001) "Price Determination in International Oil Markets: Developments and Prospects." in SARB Quarterly Bulletin. No. 219, March, pp. $69-88$.

[12] Greene, J.E. (1989) "External Debt Problem of Sub-Saharan Africa," Jacob Franket, et al (ed). Analytical Issues in Debt. Washington DC, IMF.

[13] Greene, J. E. et al. (1990) The African Debt Crisis. AERC, Nairobi.

[14] Herbst, J. (1996) Africa and the International Economy. South African Institute of International Affairs, Johannesburg, July.

[15] Kox. H. (1990) Export Constraints for Sub-Saharan Africa. Research Paper, Fred University of Amsterdam.

[16] Krumm, K.L. (1985) The External Debt of Sub-Saharan Africa: Origins, Magnitude and Implications for Action. World Bank Staff Papers No. 741.

[17] Mahmoud. M. I. (1994) "International Constraints and Economic Policy Making in African Countries" in E.L. Bacha Economics in Changing World. St. Martin's, London.

[18] Makler, H. et al (Eds.). (1982) The New International Economy. Sage Publication.

[19] Minstry, P. S. (1988) African Debt: The Case for Relief for Sub-Saharan Africa. Oxford.

[20] Morton,G.R. (2007) "The Effects of Oil Price Shocks." online article obtained fromhttp://www.sundaytimes.co.uk/news/pages/sti/2001/09/02/stibusecn03002.html

[21] Ndongko. W. A. (1995) A Conceptual Framework for Analyzing the Effects of Foreign Private Capital Flows in Developing Economies. ECA/MRAG/92/2/TP, Addis Ababa.

[22] Ndongko, W.A. (1996) Seminar on International Economic Problems. International Relations Institute of Cameroon (IRIC), Yaounde, May.

[23] Nkomo J.C.(2006) "The Impact of Higher Oil Prices on Southern African Economies," in Journal of Energy Research in Southern Africa. Vol. 17, No 1.

[24] Nwankwo, A. (2002). "Impact of Nigeria's External Debt on the Economy". Debt Management Office Monthly Seminar Series 1, Abuja.

[25] Ojo, M.O. (1994). African Debt Burden in Historical Perspective. Selected Paper for the 1994 Annual Conference of the Nigerian Economic Society, lbadan.

[26] Qureshi. Z. (1996) "Globalization, New Opportunities Tough Challenges." Finance and Development. IMF, Washington DC, March.

[27] Safadi, R. and Laird. S. (1996) "Uruguay Round Agreements: Impact on Developing Countries.” World Development. Vol. 24, No. 7.

[28] Soludo, C. (2009) Global Financial and Economic Crisis: How Vulnerable is Nigeria? www.cenbank.org/OUT/SPEECHES/2009

[29] Sommers, L. M. and Merhatu, A. (1992) "Trade Patterns and Trends in the African-European Trading Area: Lessons for SubSaharan Africa from the Era of the Lome Accords 1975 - 1988." African Development. Vol. XVII, No. 2, 1992.

[30] Turok, B. (1991) (Ed.). Alternative Strategies for Africa: Debt and Democracy. Vol. 3, Institute for African Alternatives, London.

[31] Wakeford J.J. (2006) “The Impact of Oil Price Shocks on the South African Macro-economy: History and Prospects." Paper prepared for the TIPS/DPRU forum on the theme "Accelerated and Shared Growth in South Africa: Determinants, Constraints and Opportunities" held in Johannesburg from $18-20$ October

[32] World Bank, (2003) Debt Tables Washington D.C

[33] World Bank, (2006). World Development Indicators. Washington D.C. 